\title{
Leadership of Vocational School Headship (Vocational School) Based on Religious and Integrity in the Industrial Revolution ERA 4.0
}

\author{
Sitti Hartinah, Putut Suharso, Tati Heriati, Sulfikar Sallu
}

\begin{abstract}
Good leaders have good attitudes and are obedient in following the rules of their religion. Besides, they are tolerant to others and live in harmony with other people who have different belief with them. Industrial Revolution 4.0 is an automation trend in exchanging data with the existing machines. There are several steps that can help policy makers; conformity with one another, transparency, technical assistance and independent decisions. Principal leaders need to improve capabilities, have global influence on a macro and micro basis, to build relations between students and business partners which are increasingly complex. The purpose of this study is to design the concept of leadership in this era to keep up with the existing developments. The method used was interview and did literature review by utilizing all existing technological facilities. The results were the formation of the character of a principal who has a religious spirit. Thus, leaders nowadays need to be able to blend with good professionals to students and business partners.
\end{abstract}

Index Terms: Leaders in the industrial revolution era 4.0.

\section{INTRODUCTION}

Leadership is essentially a core function in the management process.(1) The success of the school in implementing what has been planned needs to be supported by the principal of the school. The presence of the principal's leadership is very important (2) because it is a driving force for school resources especially teachers and school employees. One of the important factors of education management but still less prioritized in the education development program is the leadership of the principal. No matter how much school input is added or improved, the output will still not be optimal, if the leadership factors of the school, which are very strategic aspects in the teaching learning process, are not given adequate attention. This is because smooth input processes and positive interaction in teaching learning practices depend on the principal as the leading manager

The faced problem relates to efforts in improving the quality of education which is still unsuccessful, this is due to the education development strategy which tend to be more input oriented. Such a strategy relies more on the assumption that when all educational inputs have been

Revised Manuscript Received on April 19, 2019.

Sitti Hartinah, Teacher Training and Education Faculty, Universitas Panca Sakti Tegal, Indonesia

Putut Suharso, Faculty Of Social Culture, Universitas Diponegoro, Indonesia(Email: putut.undip@gmail.com)

Tati Heriati, Teacher Training and Education Faculty, Universitas Pasundan, Indonesia(Email: tatiheriati@unpas.ac.id)

Sulfikar Sallu Faculty Of Information Technology, Universitas Sembilanbelas November Kolaka, Sulawesi Tenggara Indonesia (Email: sulfikar.sallu@gmail.com) fulfilled, such as the provision of books (teaching materials) and other learning equipment, provision of educational facilities, training of teachers and staff to other education, educational institutions (schools ) will be able to produce expected quality output.

From the point of view of education quality management, educational leadership reflected by the principal should concern for efforts to improve the quality of education in the education unit. Related to this, the quality of education can be interpreted as the ability of educational units both technical and professional management to support the learning process so that it can achieve optimal learning achievement.

The basic concepts and principles of education management (3) must be understood by the principal, so that it will create resilience in creating superior and competitive quality schools in work. This resilience illustrates that principals must have (1) technical strength in implementing management functions; (2) human strength in utilizing the social potential of the school; (3) the strength of education and leadership; (4) symbolic strength, namely symbolic interaction of professional position; and (5) cultural strength as a value system oriented to the culture of quality and work ethic.

The leadership carries out functions (4) related to (1) developing and channeling freedom of thought and issuing opinions both individually and in groups; (2) developing an effective working atmosphere; (3) produce and encourage opinions and mutual respect; (4) helping solve good problems faced by individuals and groups.

From management education perspective, the principal as manager of educational resources (5) (6) has a decisive role for the school he or she leads. The concept of school productivity refers to a production function that reflects the relationship between educational outcomes and the resources produced to achieve predetermined educational goals, namely (1) the administrators production function; (2) the economist's production function

The factors influencing the leadership of the principals of the State Vocational School (7) are the school organizational climate and work ethic that are believed to influence it in the industrial revolution era 4.0. This is based on the assumption that principals of vocational school work in addition to expecting material and non-material rewards, they also want 
a climate based on their expectations, such as openness in the organization, attention, support, and appreciation. The creation of good climate and achievement emphasizes to workers (8) can facilitate the achievement of the desired results.

The rationale for conducting this research are (1) the new paradigm of education management at the education unit level give broad authority to principals to develop schools to be more productive; (2) the autonomy of management of education is related to authority that the principal must be able to empower the school environment in order to improve the quality of education in a sustainable manner; and (3) the nature of education reform in the cultural dimension develops new norms about roles and behavior, develops and acclimates collaboration in the learning process. Reformation in this dimension is driven by the fact of low creativity and initiative, the leadership of the headmaster in command style, the school climate is not conducive.

\section{LITERATURE REVIEW}

Leadership refers to an act of motivating subordinates to carry out tasks, and it is the most dominant aspect in the management of an organization. (9) state that leadership is the act of motivating people to perform certain activities to achieve specific goals of leadership in the most visible aspect of management. Leadership is "the ability and readiness to inspire, guide, direct, or manage other"(10)

The Leader is suggests that principals as leaders in schools have (1) the following duties and responsibilities, managing the operations of the school routine, (2) judging the worth of the school's objective and useful procedures to accomplish, (3) instituting new positions which result in better education for students, and (4) welding professionals of the staff into a cohesive force (11) states that the transformational leadership model that inspires followers to direct personal interests for the good of the organization, recognizes values and philosophy, and thinks of problems in new ways, influences followers and forms positive images, has a strong influence on achieving productivity (12)

Transformational leadership is described as a form of leadership that is able to increase staff commitment (13) communicating a vision and its implementation (14) giving satisfaction in working and developing a client-oriented focus.(15) offer more direct leadership within an organization.

The concept of competency as stated by (16) (17) is an area of knowledge or skill that is critical for production to outputs. Furthemore, the competencies area of internal capabilities that people bring to their jobs; capabilities which may be expressed in a broad, infinite event array of on the job behavior. (18) (19) (20)

competencies are "result of orientation, influence, initiative, flexibility, concern for quality, technical expertise, analytical thinking, conceptual thinking, team work, service orientation, interpersonal awareness, relationship building, cross cultural sensitivity, strategic thinking, entrepreneurial orientation, building organizational commitment, and empowering others, developing others (21). factors forming the school's organizational climate, namely (1) disengagement; (2) obstacles (hindrance); (3). Enthusiasm (esprit); (4) intimacy; (5) distance (aloofness; (6) pressure on results (production emphasis); (7) encouragement (thrust; and (8) consideration. Halpin and Croft (1987) mention factors resulting the school's organizational climate, namely (1 ) disengagement; (2) obstacles (hindrance); (3). enthusiasm (esprit); (4) familiarity (intimacy); (5) distance (aloofness; (6) pressure on results (production emphasis); ( 7 ) encouragement (thrust, and (8) consideration.

Experts explains that values in an organizational climate are organizational conditions that are able to provide flexibility to act for employees / teachers in carrying (22) out assigned tasks, feeling in carrying out tasks so that the organization is inspired by all of its members. Further expalin that what is meant by organizational climate is the overall physical and social factors,(23) (24) the state of the physical structure of the school that can affect comfort in carrying out its work.

\section{METHOLOGY}

This research is descriptive correlational with the characteristics of an analysis of the relationship between endogenous variables of the principal's competence, school organizational climate, and work ethic with the exogenous variables of the principal's transformational leadership. In accordance with the construct of causal relationships between variables, a quantitative approach was used with analysis of confirmatory factor analysis through LISREL. The researchers wanted to find systematic and empirical data. Besides, the researchers did not directly control the independent variable because the event has occurred and it cannot be manipulated.

In this study, a quantitative approach is used with nonexperimental research design. Some steps taken in this study are (1) formulating problems, identifying problems, and determining research objectives; (2) determining concepts and hypotheses and exploring literature; (3) determining the sample; (4) organizing a questionnaire; (5) doing field work; (6) processing data; (7) analyzing and reporting (Kerlinger 1986: 119) in accordance with survey research with an exploratory and confirmatory quantitative approach.

The conceptualization the flow chart model is arranged as shown in Figure 1 below:

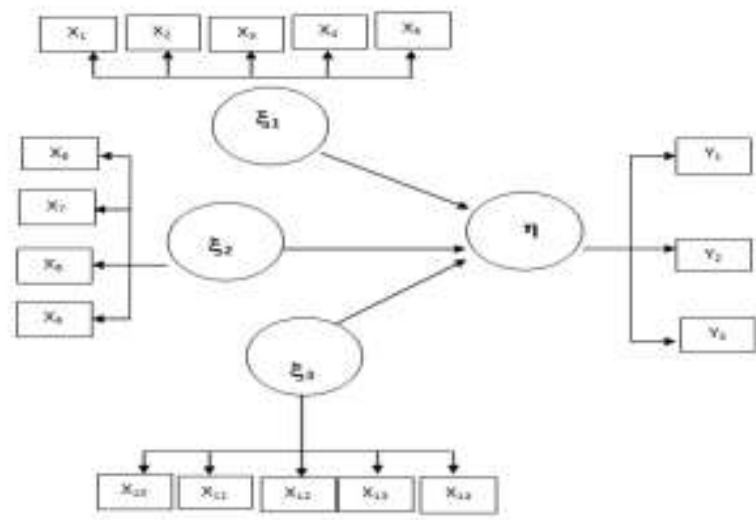

Figure 1. Flow chart of the influence of principals' competencies, school organizational climate, and work ethic on the principal's transformational leadership 


\section{RESULT AN FINDINGS}

\subsection{Analysis of Confirmatory Factors}

Confirmatory measurement of the principal competency variable as the first exogenous latent variable, measured by five indicators, consisting of personality competencies (X1), managerial competence (X2), entrepreneurial competence (X3), supervision competence (X4), and social competence (X5).

Confirmatory tests of principals' competencies are stated to be fit properly, this is proved from the probability test value of $0.647>0.05$, and a small chi square coefficient value of 3.345 . This value is matched with the cut of value (chi square table at the level of $\square=0.05$; DF $=5$ ) with the results obtained from the Chi-Square table value of 11.075. Confirmatory testing of principal competence can be seen in Figure 2 below.

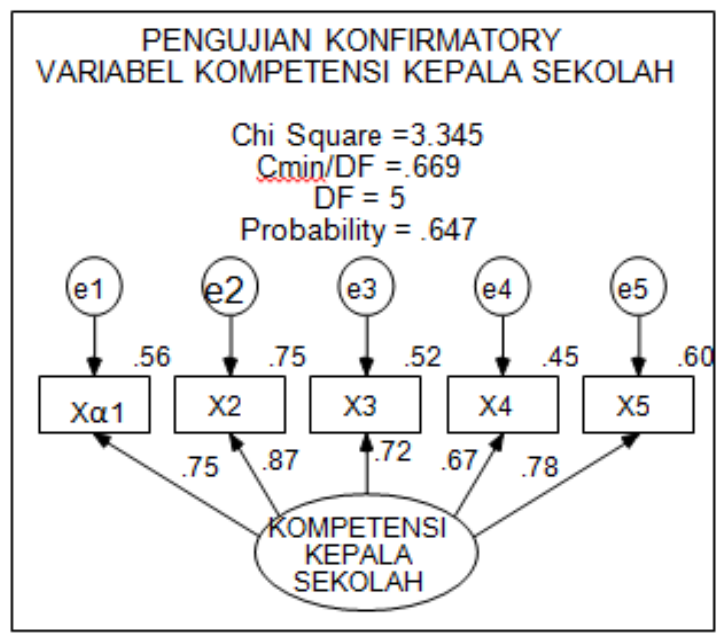

Figure 2. Testing of Confirmation of Principal Competence

The conclusions obtained from the confirmatory competency testing model of the principal are in accordance with the data. The significance of the regression coefficients for each dimension on the principal competency variable is at the level of $2 / 2(0.025)$, or equal to \pm 1.96 . Through a comparison between the $\mathrm{CR}$ value (critical ratio) and the $\mathrm{Z}$ value of the table, it turns out that for all dimensions proved to be greater than the value of $\mathrm{Z}$ table, or seen from the So it was concluded that the factor loading coefficients produced for all dimensions on the principal's competency were significant.

Confirmatory measurements of school organizational climate variables as the second exogenous latent variable have four indicators or observational variables, namely psychological dimensions (X6), structural dimensions (X7), social dimensions (X8), and bureaucratic dimensions (X9). Testing of the school organization climate variables can be seen in Figure 3 as follows. probability value $(\mathrm{P})$, all dimensions are smaller than 0.05 .

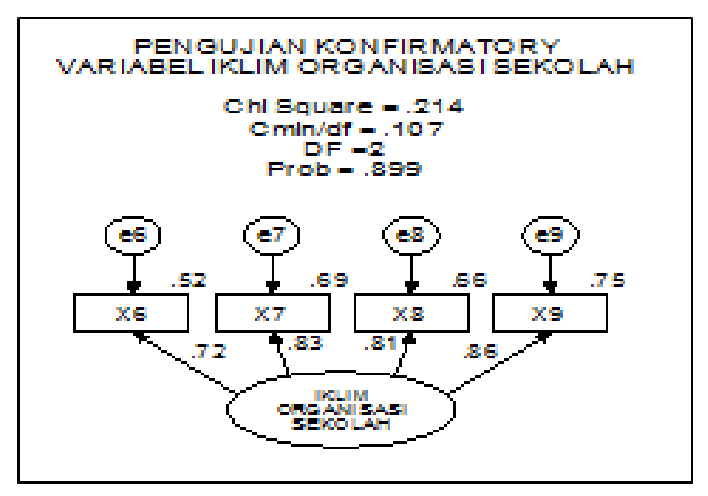

\section{Figure 3 Confirmatory Testing of School Organizational Climate Variables}

Based on Figure 3, it can be stated that the confirmatory testing of the School Organization Climate is stated to be fit properly, this is proved by the probability test value of $0.107>0.05$, and the small chi square coefficient value of 0.214 . This value is confirmed by the cut of value (chi square table at the level of $\square=0.05$; DF $=4$ ) with the results obtained from the Chi-Square table value of 5.992.

It can be concluded that the school organization climate confirmatory testing model are in accordance with empirical data. The significance of the regression coefficients can be stated that each dimension of the school organization climate variable is significant at the level of $2 / 2(0.025)$, or equal to \pm 1.96 . Through a comparison between the $\mathrm{CR}$ value (critical ratio) and the $\mathrm{Z}$ value of the table, it turns out that for all dimensions proved to be greater than the value of $\mathrm{Z}$ table, or seen from the probability value $(\mathrm{P})$, all dimensions are smaller than 0.05 . So it was concluded that the factor loading coefficient generated for all dimensions in the school organizational climate was significant.

Confirmatory measurement of work ethic as the third exogenous latent variable has 5 indicators to be tested including the work moral dimension (X10), low absenteeism dimension (X11), high accountability dimensions (X12), high motivation dimensions (X13), and dimensions of commitment to organizational vision. (X14). Testing of these variables can be seen in the following figure.

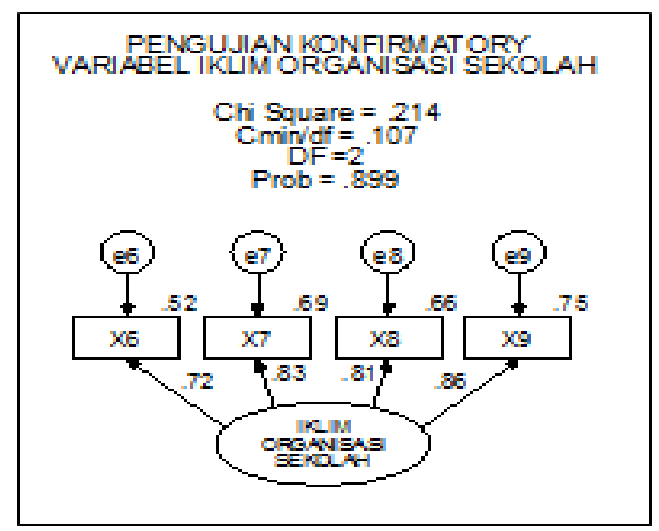

Figure 4. Confirmatory Testing of School Organization Climate Variables 
Based on Figure 4, it can be stated that the confirmatory testing of the School Organization Climate is stated to be fit properly, this is evidenced by the probability test value of $0.107>0.05$, and the small chi square coefficient value of 0.214 . This value is confirmed by the cut of value (chi square table at the level of $\square=0.05$; DF $=4$ ) with the results obtained from the Chi-Square table value of 5.992.

The conclusions obtained by the school organization climate confirmatory testing model are in accordance with empirical data. The significance of the regression coefficients can be stated that each dimension of the school organization climate variable is significant at the level of $\square /$ 2 (0.025), or equal to \pm 1.96 . Through a comparison between the $C R$ value (critical ratio) and the $\mathrm{Z}$ value of the table, it turns out that for all dimensions proved to be greater than the value of $\mathrm{Z}$ table, or seen from the probability value $(\mathrm{P})$, all dimensions are smaller than 0.05 . So it was concluded that the factor loading coefficient generated for all dimensions in the school organizational climate was significant.

Confirmatory measurement of work ethic as the third exogenous latent variable has 5 indicators to be tested including the work moral dimension (X10), low absenteeism dimension (X11), high accountability dimensions (X12), high motivation dimensions (X13), and dimensions of commitment to organizational vision. (X14). Testing of these variables can be seen in the following figure.

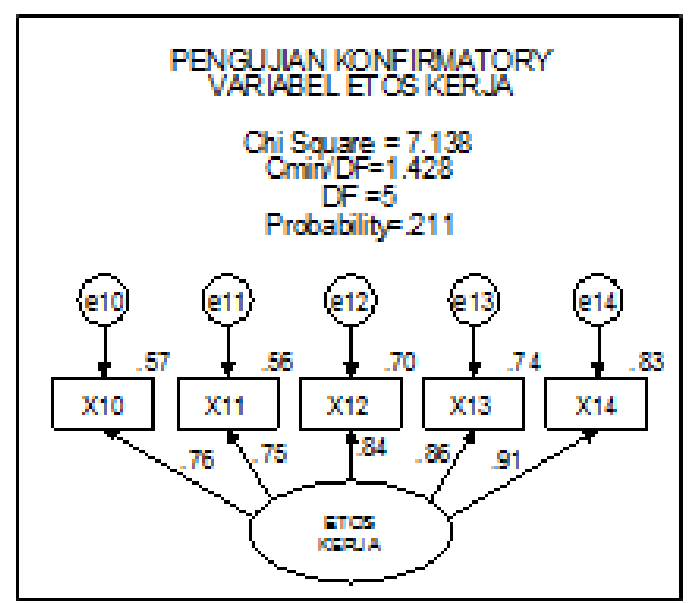

Figure 5. Confirmatory Test of Work Ethics

Based on Figure 5, it can be stated that the confirmatory test on the dimensions of the work ethic is stated to be fit properly, this is proved by the probability test value of $0.211>0.05$, and the small chi square coefficient value is 7.138. This value is matched with the cut of value (chi square table at the level of $\square=0.05$; DF $=5$ ), with the results obtained from the Chi-Square table value of 11.075.

The conclusions obtained by the work ethic confirmatory testing model are in accordance with the data. The significance of the regression coefficient can be stated that each dimension in the work ethic variable is significant at the level of $\square / 2(0.025)$, or equal to \pm 1.96 . Through a comparison between the $\mathrm{CR}$ value (critical ratio) and the $\mathrm{Z}$ value of the table, it turns out that for all dimensions proved to be greater than the value of $\mathrm{Z}$ table, or seen from the probability value $(\mathrm{P})$, all dimensions are smaller than 0.05 . So that it can be concluded that the factor loading coefficients produced for all dimensions in the work ethic are stated to be significant, it can be seen from each dimension namely the work moral dimension $(\mathrm{r}=0.756$; $\mathrm{p}$ $<0.00)$, low absenteeism dimensions $(r=0.749$; $p<0,00)$, accountability dimensions $(r=0,836 ; \mathrm{p}<0,00)$, dimensions of motivation and morale $(r=0,859 ; \mathrm{p}<0,00)$, dimensions of commitment to organizational vision $(\mathrm{r}=0,915 ; \mathrm{p}<$ 0.00).

Confirmatory measurement of the principal's transformational leadership as an endogenous latent variable, which has three indicators, namely, variable measurement of charisma (Y1), intellectual sensitivity (Y2), and intellectual stimulation (Y3). Testing of these variables can be seen in Figure 6, as follows.

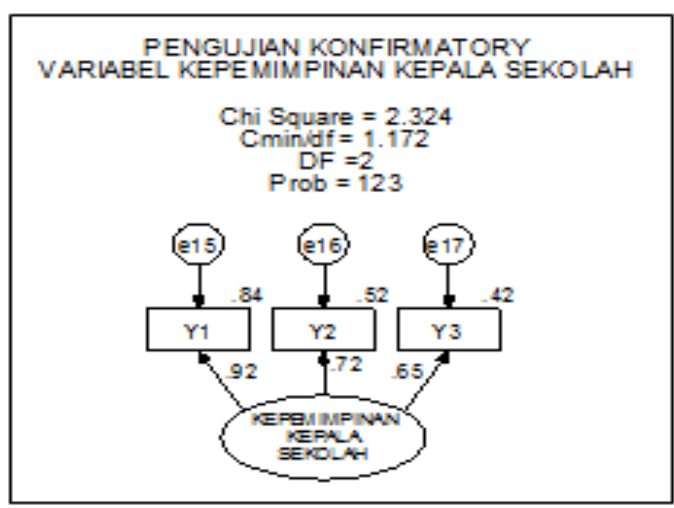

Figure 6. Confirmatory Testing of Principal Leadership

Based on Figure 6, it can be argued that the principal transformational leadership confirmatory testing is properly fit, this is proved by the probability test value of $0.123>$ 0.05 , and the small value of the chi square coefficient is 2.324. The value is when matched with the cut of value (chi square table at the level of $\square=0.05$; DF $=2$ ) with the results obtained from the Chi-Square table value of 5.992 .

The conclusions obtained by the principal's transformational leadership confirmatory testing model are in accordance with empirical data. The significance of the regression coefficients can be stated that each dimension of the principal transformational leadership is significant at the level of $2 / 2(0.025)$, or equal to \pm 1.96 . Through a comparison between the $\mathrm{CR}$ value and the $\mathrm{Z}$ value of the table, it turns out that for all dimensions it is greater than the $\mathrm{Z}$ value of the table, or seen from the probability value $(\mathrm{P})$ that all dimensions are smaller than 0.05 , namely the dimension of charisma $(r=0,915 ; \mathrm{p}<0,00)$, dimensions of intellectual sensitivity $(\mathrm{r}=0,719 ; \mathrm{p}<0,00)$, and dimensions of intellectual stimulation $(r=0,650 ; p<0,00)$ It can be concluded that the factor loading coefficient is generated for all dimensions the principal's leadership was significant.

Confirmatory measurements of exogenous variables, namely the explanatory variables consist of three latent variables, namely the principal competency variable $(\xi 1)$, school organizational climate variables $(\xi 2)$, and work ethic variables ( $\xi 3)$. Testing of exogenous variables can be seen in Figure 7 below. 


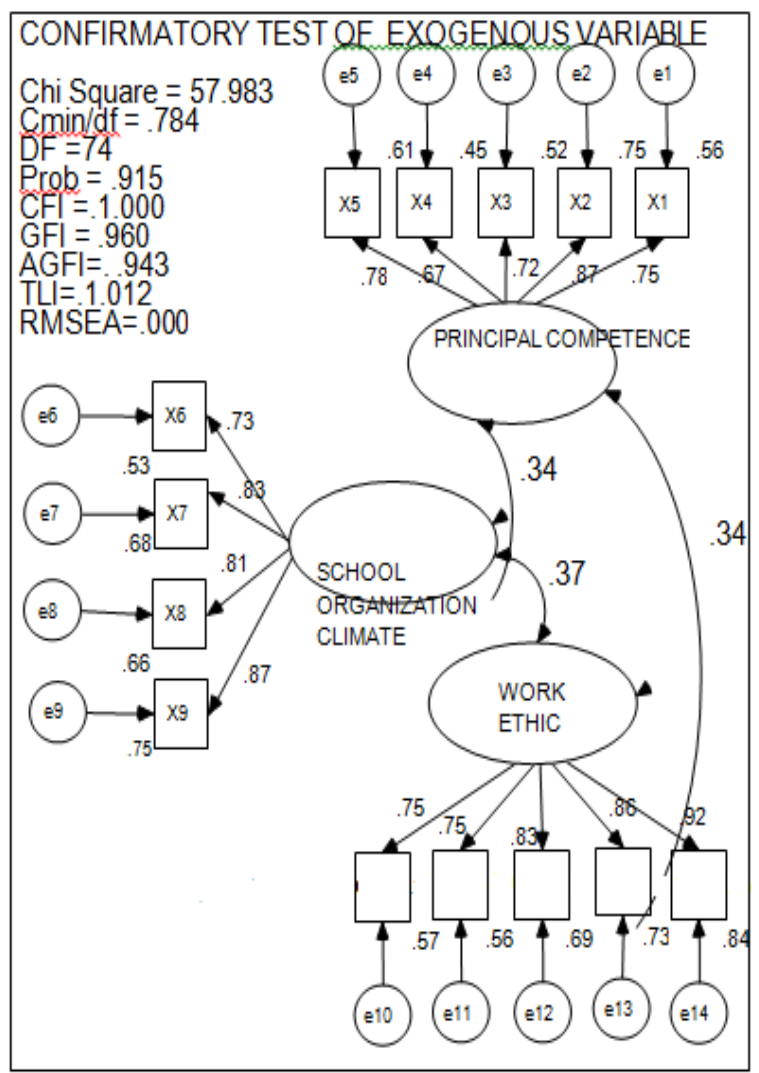

Figure 7. confirmatory test of the exogenous variable

Based on Figure 7, it can be stated that the confirmatory test of the exogenous variableis stated to be fit properly, this is evidenced by the probability test value of $0.915>0.05$, and the small chi square coefficient value of 57.983. The value is when matched with the cut of value (chi square table at the level of $\square=0.05$; DF $=74$ ) with the results obtained from the Chi-Square table value of 95.082.

The conclusions obtained from the exogenous variable confirmatory testing model are in accordance with empirical data. The significance of the regression coefficients can be stated that each dimension in the exogenous variable is significant at the level of $2 / 2(0.025)$, or equal to \pm 1.96 . Through a comparison between the value of CR (critical ratio) and the $Z$ value of the table, it turns out that for all dimensions proved greater than the value of $\mathrm{Z}$ table, or seen from the probability value $(\mathrm{P})$, all dimensions are smaller than 0.05 , so it can be concluded that the factor loading produced for all dimensions in the exogenous variable was significant.

Structural Analysis of Equation Model (SEM)

Full Model Structural Equation Model (SEM) means to test the proposed hypothesis and to answer the problem statement. In this analysis, there are three variables; three latent variables are the principal competency variable ((1),

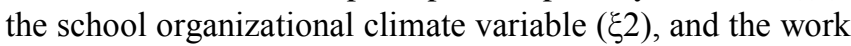
ethic variable $(\xi 3)$, as a test of exogenous variables. Meanwhile the variable described is the principal's transformational leadership variable with the eta symbol $(\eta)$.

Furthermore, the structural equation model (SEM) model is built from three constructs which cover the competency of the principal covering 5 indicators, the climate of the school organization that is constructed with 4 indicators and the work ethic constructed with the five indicators stated to be fit properly, this is proved by the feasibility of Test values as shown in Table 1 below.

Table 1. Feasibility Testing Index of Structural Equation Modeling

\begin{tabular}{lllll}
\hline No & $\begin{array}{l}\text { Goodness } \\
\text { of fit index }\end{array}$ & Cut of value & $\begin{array}{l}\text { Analysis } \\
\text { Result }\end{array}$ & $\begin{array}{l}\text { Evaluation } \\
\text { Model }\end{array}$ \\
\hline 1 & $\begin{array}{l}\mathrm{X}^{2}-\text { Chi- } \\
\text { Square }\end{array}$ & $<141.030$ & 135,609 & Good \\
\hline
\end{tabular}

2 Significance $>\quad 0,05 \quad 0,103 \quad$ Good Probability

$\begin{array}{lllll} & \text { CFI } & > & 0,989 & \text { Good } \\ 3 & \text { GFI } & 0,90 & & \\ & & > & 0,923 & \text { Good } \\ 4 & \text { AGFI } & 0,90 & & \\ & & & & \\ 5 & \text { TLI } & 0,90 & 0,899 & \text { Good } \\ & & & & \\ 6 & \text { RMSEA } & 0,95 & 0,987 & \text { Good } \\ & & <0,08 & 0,029 & \text { Good }\end{array}$

Based on table 1, it can be stated that the planned model is good, because after being tested for its compatibility with the Chi Square, GFI, AGFI, TLI, and RMSEA values compared to the cut-off value of the structural model equation, the results are found in the good category, the chi square probability value ( $\mathrm{p}$ value) is $0.103>0.05$. It can be concluded that the model is in accordance with the data or fit to the data used in this study.

Convergent Validity Test

Convergent validity tests are obtained from measurement model data, this test is conducted to determine the validity of each estimated indicator, by measuring the dimensions of each concept tested in the study. Each indicator has a nadir (critical ratio) that is greater than the value of table $\mathrm{Z}$ with a significant level Good / 2 (0.025), or equal to \pm 1.96 . Through a comparison between the $\mathrm{CR}$ value and the $\mathrm{Z}$ table value, it turns out that for all dimensions are proven to be greater than the $\mathrm{Z}$ table value, or seen from the probability value $(\mathrm{P})$ that all dimensions are smaller than 0.05 so it can be concluded that the factor coefficient loading generated for all dimensions is significant. This means that it measures what should be measured on the presented model. The significance of the regression coefficients is shown in Table 2 below 
Table 2. Regression Coefficient Results of Calculation of SEM Analysis

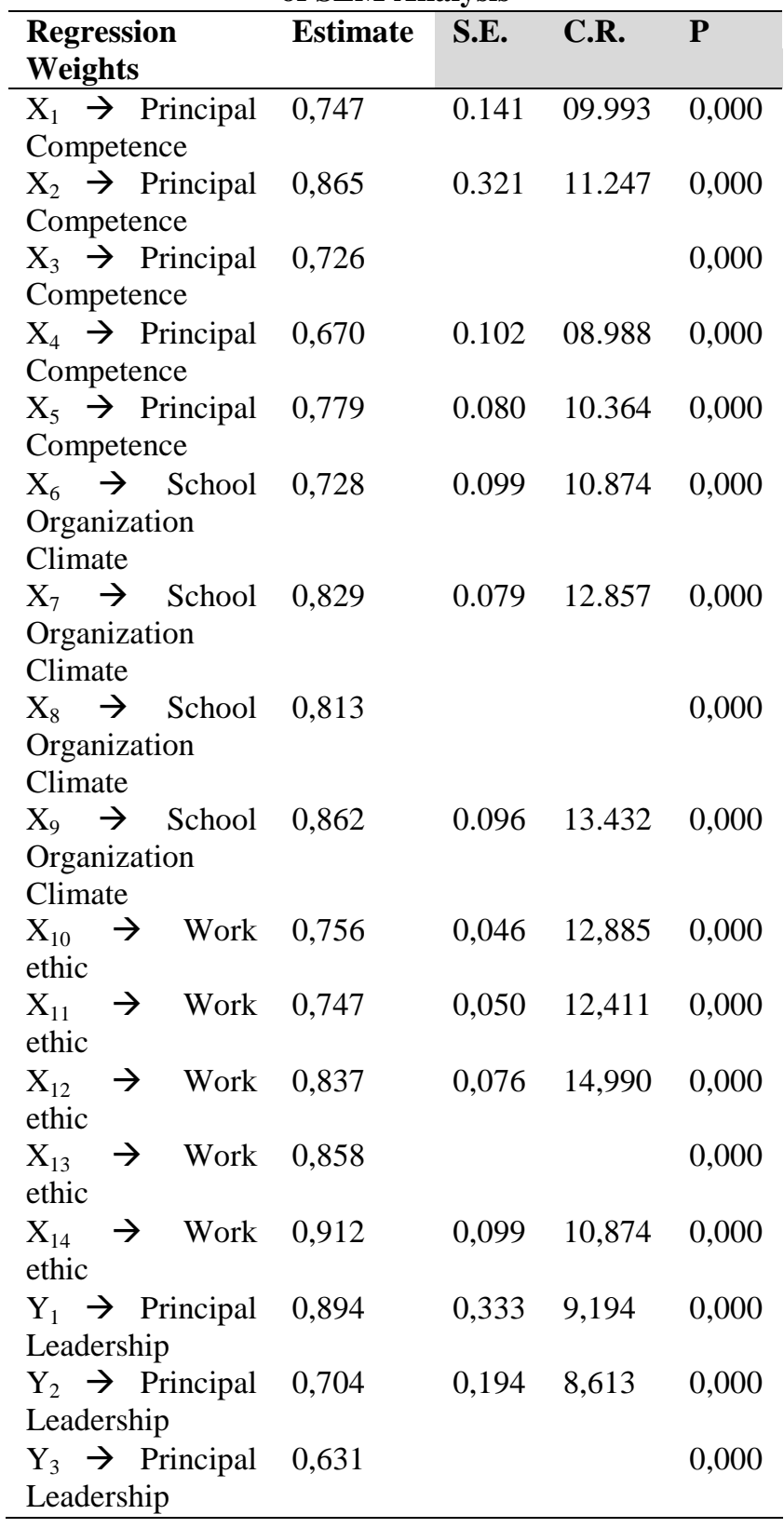

Based on Lisrel's output, as presented in table 2, it can be seen that the direction of the relationship between exogenous latent variables with endogenous latent variables shows a positive direction, and none of the structural models tested with empirical data can be used to test hypotheses all formulated in the form of positive directions.

Furthermore, the relationship between variables in the model can be explained as follows.

1. The variable that has the most influence on the principal's transformational leadership is the charisma factor $(\mathrm{r}=0.894)$; followed by intellectual sensitivity factor $(\mathrm{r}=$ $0.704)$; and the smallest effect is the indicator of intellectual stimulation $(\mathrm{r}=0.631)$.

2. The variable that has the most influence on the competency of the principal is the managerial competency factor $(r=0.865)$; social competency factor $(r=0.779)$; personality competency factor $(r=0.747)$; entrepreneurial competency factor $(r=0.779)$; and the least influential is the principal competency factor indicator in supervision $(\mathrm{r}=$ $0.631)$.

3. The variables that have the most influence on the school's organizational climate are bureaucratic dimensions $(r=0.862)$; structural dimension factors $(r=0.829)$; social dimension factor $(r=0.813)$; and the least influential is the personality dimension indicator $(r=0.728)$.

4. The variable that has the most influence on the work ethic is the factor of commitment to the organization's vision $(\mathrm{r}=0.912)$; high motivation and motivation factors $(\mathrm{r}=$ $0.858)$; high accountability factor $(\mathrm{r}=0.837)$; work moral factor $(\mathrm{r}=0.756)$; and the least influential is a low indicator of absenteeism $(r=0.747)$.

The assessment of the structural model is intended to ensure the support of empirical data on the hypothesized model. The calculation results generated empirical data supporting the hypothesized model.

\section{CONCLUSION}

. The results of the study found that the principal's transformational leadership model was constructed with buildings on the principal competency variables, the school's organizational climate and work ethic were fit models. This result is in accordance with the desired theory stated that if there is an increase in the competency of the principal, the school's organizational climate and work ethic, then there will be an increase in the principal's transformational leadership in the same direction namely positive direction.

Managerial competency shows that principals in leading schools in order to utilize school resources optimally. The principal must be competent in managing school change and development towards an effective and efficient learning organization. The biggest constructor is managerial competence, this is in accordance with the desired theory, but it does not mean that the other competencies are meaningless.

Principals lead through exemplary by combining the right structure and good direction according to the situation. The principal in this case is bureaucratic who can create school climate which is conducive in achieving goals, namely effective school.

The results of this study explain that charisma for a leader in this case the principal is regarded as important thing besides the other dimensions such as soft skills for the principal him or herself. Principals who have charisma in carrying out their duties, subordinates including teachers and educators may feel happy with the charisma they have. With the charisma of the principal, the leadership of the principal can be effective.

\section{ACKNOWLEDGMENT}

Dinas Pendidikan, Central Java Province

\section{REFERENCES}

1. Pearce, C.L., et al., Toward a theory of meta-paradoxical leadership. Organizational Behavior and Human Decision Processes, 2019. 
2. Al-Mahdy, Y.F.H., M.M. Emam, and P. Hallinger, Assessing the contribution of principal instructional leadership and collective teacher efficacy to teacher commitment in Oman. Teaching and Teacher Education, 2018. 69: p. 191-201.

3. fakhri, L.s. and F. Talebzadeh, A framework for Professional citizenship education based on knowledge management principles. Procedia - Social and Behavioral Sciences, 2011. 29: p. 1133-1142.

4. Daniëls, E., A. Hondeghem, and F. Dochy, A review on leadership and leadership development in educational settings. Educational Research Review, 2019. 27: p. 110 125.

5. Sirbu, C.C., et al., Aspects Related to Management Styles and Manager Types in the Educational Organizations. Procedia - Social and Behavioral Sciences, 2015. 182: p. 555-559.

6. Behbahani, A., Educational leaders and role of education on the efficiency of schools principals. Procedia - Social and Behavioral Sciences, 2011. 15: p. 9-11.

7. Bakar, R., The influence of professional teachers on Padang vocational school students' achievement. Kasetsart Journal of Social Sciences, 2018. 39(1): p. 6772.

8. Caique Z. Kiriloa, J.M.A., Luiz A. de Limaa, Luiz Carlos Machi Lozanoa, Marcelo Nogueiraa,b, Cristina Correa de Oliveirac, Kazumi Nakamatsud, Organizational Climate Assessment Using the Paraconsistent Decision Method. 8th International Congress Of Information and Communication Technology, 2018: p. 11.

9. Tri Jaka Kartana, KONTRIBUSI FAKTOR DETERMINASI DAN UPAYA PENINGKATAN KINERJA GURU TEKNIK MESIN SEKOLAH MENENGAH KEJURUAN. 2000: p. 10.

10. Hao, Y., Exploring undergraduates' perspectives and flipped learning readiness in their flipped classrooms. Computers in Human Behavior, 2016. 59: p. 82-92.

11. Masci, C., K. De Witte, and T. Agasisti, The influence of school size, principal characteristics and school management practices on educational performance: An efficiency analysis of Italian students attending middle schools. Socio-Economic Planning Sciences, 2018. 61: p. 52-69.

12. Dhanesh, G.S. and G. Duthler, Relationship management through social media influencers: Effects of followers awareness of paid endorsement. Public Relations Review, 2019: p. 101765.

13. Parr, A.D., S.T. Hunter, and G.S. Ligon, Questioning universal applicability of transformational leadership: Examining employees with autism spectrum disorder. The Leadership Quarterly, 2013. 24(4): p. 608-622.

14. Uzarski, D. and M.E. Broome, A Leadership Framework for Implementation of an Organization's Strategic Plan. J Prof Nurs, 2019. 35(1): p. 12-17.

15. Strickler, A., J.R. Mihalo, and K.L. Celedonia, Reducing barriers to using data: A learning collaborative approach to leverage collective knowledge about treatment parent satisfaction and retention. Children and Youth Services Review, 2018. 95: p. 300-307.

16. Michael, M., et al., Application of Curriculum Mapping Concepts to Integrate Multidisciplinary Competencies in the Care of Older Adults in Graduate Nurse Practitioner Curricula. J Prof Nurs, 2019. 35(3): p. 228-239.

17. Traicoff, D., et al., Developing standardized competencies to strengthen immunization systems and workforce. Vaccine, 2019. 37(11): p. 1428-1435.

18. Teece, D.J., Technological Innovation and the Theory of the Firm. 2010. 1: p. 679-730.
19. Perera, H.N., et al., The human factor in supply chain forecasting: A systematic review. European Journal of Operational Research, 2019. 274(2): p. 574-600.

20. Haghighi Rad, F. and S.M. Rowzan, Designing a hybrid system dynamic model for analyzing the impact of strategic alignment on project portfolio selection. Simulation Modelling Practice and Theory, 2018. 89: p. 175-194.

21. Hanaysha, J., Examining the Effects of Employee Empowerment, Teamwork, and Employee Training on Organizational Commitment. Procedia - Social and Behavioral Sciences, 2016. 229: p. 298-306.

22. Hines, A. and J. Gold, An organizational futurist role for integrating foresight into corporations. Technological Forecasting and Social Change, 2015. 101: p. 99-111.

23. Nicolletti, M., et al., Social and organizational learning in the adaptation to the process of climate change: The case of a Brazilian thermoplastic resins and petrochemical company. Journal of Cleaner Production, 2019. 226: p. 748-758.

24. Kang, H.J. and J.A. Busser, Impact of service climate and psychological capital on employee engagement: The role of organizational hierarchy. International Journal of Hospitality Management, 2018. 75: p. 1-9.

\section{AUTHORS PROFILE}

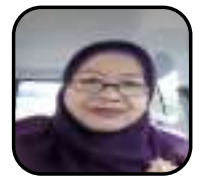

Sitti Hartinah S1 Department of Education, Faculty of Education, iSurakarta State University, S2 Human Resource Management University of Muhammadiyah Jakarta S3 Management Education, Semarang State University

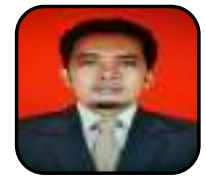

Putut Suharso, S1 Information and Library Science at Padjadjaran University, S2 Information and Library Management at Gadjah Mada University. Currently he is pursuing his doctoral education in Cultural Studies at the Graduate School of Sebelas Maret University, Surakarta. As a permanent lecturer in the study program of Library and Information Sciences at Diponegoro University. Research studies related to the problem of education, library management and community empowerment. ID Scopus 57202748984, e-mail: putut.undip@gmail.com

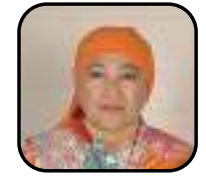

Tati Heriati Undergraduate IKIP Bandung, S2 S3 Postgraduate IKIP Bandung. Permanent Lecture at Universitas Pasundan Bandung, West Java Indonesia. Primary School Teacher Education. Email: tatiheriati@unpas.ac.id

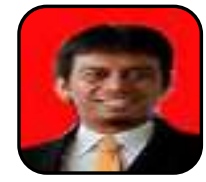

Sulfikar Sallu, S1 Informatics Engineering and S2 Master of Computer Science, Postgraduate Doctora Degree in Educational Technology at Universitas Negeri Jakarta Permanent Lecturer at Universitas Sembilanbelas November Kolaka, Southeast Sulawesi, Indonesia, has two professional certificates, Information Technology Infrastructure Library (ITIL) and Microsoft Technology Associate (MTA) ID Scoopus 57200989289, email : sulfikar.sallu@gmail.com 